\title{
Mycobacterium vaccae Immunization to Pregnant BALB/c Mice Ameliorated Lung Histopathology and Bone Marrow Eosinophila in Ovalbumin Sensitized Offsprings
}

\author{
Tunc Akkoc*, Cevdet Ozdemir, Didem Yazi, Ozlem Yesil, Nerin Nadir Bahceciler, Isil Barlan \\ Pediatric Allergy and Immunology Division, School of Medicine, Marmara University, Istanbul, Turkey \\ Email: tuncakkoc@marmara.edu.tr
}

Received 9 March 2014; revised 9 April 2014; accepted 16 April 2014

Copyright (C) 2014 by authors and Scientific Research Publishing Inc. This work is licensed under the Creative Commons Attribution International License (CC BY). http://creativecommons.org/licenses/by/4.0/ cc) (i)

\begin{abstract}
Context: One of the treatment strategies for atopic diseases is to skew immune response away from Th2 dominance by using Mycobacterial strains. Objective: We wanted to find out whether $M$. vaccae administration to pregnant mice had any preventive effect on the offsprings in the development of a murine asthma model. Materials and Methods: Pregnant BALB/c mice were divided into two groups; first group received heat-killed $M$. vaccae subcutaneously on $12^{\text {th }}$ day of pregnancy and the latter group received PBS. After delivery, newborn mice of each group were further divided into two subgroups as M. vaccae/Ovalbumin (OVA), M. vaccae/control, PBS/OVA and PBS/ control. To establish experimental murine asthma model, mice were intraperitoneally sensitized and challenged intratracheally with Ovalbumin. We analysed airway histopathology, bone marrow eosinophil progenitors and splenic cell cytokine profiles of the offsprings. Results: Comparison of offsprings in M. vaccae/OVA group were not different than PBS controls with respect to thicknesses of airway epithelium, basement membrane, subepithelial smooth muscles and number of hyperplasic goblet cells as well as bronchial associated lymphoid tissue density and eosinophil progenitors in the bone marrow. Comparison of $M$. vaccae/OVA group to asthma model revealed significant differences and lower levels of OVA-induced IL-5. Conclusions: We propose that immunization of pregnant BALB/c with $M$. vaccae could prevent histopathological alterations in the airways related to the asthma model and down-regulates IL-5 secretion from splenocytes of offsprings.
\end{abstract}

"Corresponding author.

How to cite this paper: Akkoc, T., et al. (2014) Mycobacterium vaccae Immunization to Pregnant BALB/c Mice Ameliorated Lung Histopathology and Bone Marrow Eosinophila in Ovalbumin Sensitized Offsprings. Open Journal of Immunology, 4, 31-41. http://dx.doi.org/10.4236/oji.2014.42005 


\section{Keywords}

\section{BALB/c, Murine Asthma Model, Mycobacterium vaccae, Ovalbumin, Pregnancy}

\section{Introduction}

The prevalence of allergic disease and asthma has increased dramatically over the last few decades. This increasing prevalence of the dysregulated mucosal $\mathrm{T}$ helper (Th) 2 responses characterizing allergic pathology have typically been framed in terms of reduced or absent stimulation by Th1 polarizing stimuli. Recently called the "hygiene hypothesis", the predominant model has suggested that dramatic increase in allergic disorders have inverse correlation with reduced exposure to childhood bacterial and viral infections. Also this hypothesis highlighted elimination of chronic Th2 polarizing stimuli which was supported by Shirakawa et al. who demonstrated a strong inverse relationship between atopy and infection with or exposure to Mycobacterium tuberculosis [1]-[4].

The etiology of allergic asthma is multifactorial and involves genetic factors as well as individual history of exposure to airborne allergens and pathogens [5]-[7]. Epidemiological studies have highlighted maternal asthma as an additional risk factor for developing the disease during childhood [8]-[10]. Apparently greater influence of maternal versus paternal asthma supports the idea that, besides genes, maternal immune status including the allergic conditions may be more critical to transferring asthma risk [11]. It was suggested that maternal asthma had additional risk for offsprings for an originally sensitized allergen.

Among the Mycobacterium species, saprophytic Mycobacterium vaccae (M. vaccae) was shown to be a potent inducer of Th1 immune response. $M$. vaccae is mainly being studied for use as an immunotherapeutic agent together with chemotherapy in the treatment of tuberculosis and other diseases, such as cancer, atopic dermatitis, and psoriasis [12]. Studies also showed that $M$. vaccae has been able to supress allergic and asthma-like responses in mice [13]-[15]. Furthermore, we demonstrated that treatment of newborn mice with heat-killed $M$. vaccae significantly reduced the number of goblet cells, the thickness of the basement membrane and subepithelial smooth muscle after subsequent allergen sensitization and challenge [16]. In these studies, the exposure to Th1-inducing mycobacterial infections was suggested to cause a shift from Th2 to Th1 immune responses, which subsequently prevent the development of allergy [17]. The allergy suppressive effects of $M$. vaccae in mice are due to the induction of IL-10 and TGF- $\beta$ producing T cells [18]. The hypothesis that early exposure to this Th1 stimuli even during in utero may prevent late diseases led us to perform these concurrent experiments. To understand this, we analysed whether M. vaccae administration to pregnant BALB/c mice has any role in the development of a forthcoming murine asthma model in the offsprings. So far, there are no data concerning the effect of $M$. vaccae in pregnant mice.

\section{Methods}

\subsection{Mice}

Five to 6-week-old pregnant BALB/c mice $(\mathrm{n}=10)$ were obtained from TUBİTAK (The Scientific and Technical Research Council of Turkey; Gebze, Kocaeli) and housed according to the National Institutes of Health Guidelines. Experimental protocols were ethically approved and complied with the Animal Research Committee of Marmara University (Istanbul, Turkey).

\subsection{Preparation of $M$. vaccae}

M. vaccae (ATCC 29678 strain) was supplied from North Carolina State University and was cultured in Lowenstein-Jensen medium (REMEL, Lenexa, KS). After 3 - 4 weeks in the culture, the vials were centrifuged and re-suspended in PBS. Vials were autoclaved at $120^{\circ} \mathrm{C}$ for 25 minutes. Logarithmic dilutions of the cells were made into sterile vials. Aliquots of $1 \times 10^{7}$ Colony Forming Units (CFU)/ml in medium for subcutaneous administration were prepared and frozen at $-20^{\circ} \mathrm{C}$ until analysis. 


\subsection{Immunization of Pregnant BALB/c Mice with $M$, vaccae}

Pregnant BALB/c mice were divided into two groups (5 pregnant mice in each group); mice in the first group received $10^{7}$ colony-forming units (CFU) of heat killed M. vaccae subcutaneously on $12^{\text {th }}$ day of pregnancy and the latter group received only PBS and served as controls. The day when plaque was seen after mating was accepted as day 1 of pregnancy. After labour newborn mice of each group (6 - 7 siblings from each pregnant mice) were further divided into two subgroups named as experimental Th1 group (M. vaccae/OVA), M. vaccae/control group, experimental Th2 group (PBS/OVA) and PBS/control group $(\mathrm{n}=15$, each). Study design is presented in Figure 1.

\subsection{Establishment of Experimental Murine Asthma Model}

To establish murine experimental asthma model, starting at day 42 of offsprings' life, mice in both experimental Th1 and experimental Th2 groups received $10 \mu \mathrm{g}$ of ovalbumin (OVA) (Sigma, St Louis, Mo, USA) in 100 $\mu \mathrm{l}$ of saline intraperitoneally (i.p.) for 7 times on each alternate days. On the other hand, mice in $M$. vaccae/ control and PBS/control received only $100 \mu \mathrm{l}$ of saline i.p. to serve as study controls. Allergen challenge was performed on days 82,85 and 88 via intratracheal route by administration of $20 \mu \mathrm{g}$ of OVA in $10 \mu \mathrm{l}$ of saline under a stereomicroscope after the mice were anaesthetized [19].

\subsection{Histopathologic Analyses}

Twenty-four hours after the last intratracheal instillation, mice in all groups were sacrificed and lungs were fixed for histopathologic evaluation and inflated by intratracheal instillation of buffered formol solution. Then, lungs were removed and placed in buffer solution. Subsequently, lungs were embedded into paraffin for preparation of histopathological sections. 3 - $5 \mu \mathrm{m}$ thick tissue sections were affixed to microscope slides and the paraffin washed. The slides were stained with Hematoxylin \& Eosin (H \& E) for the evaluation of epithelial thickness and Periodic Acid-Schiff (PAS) to analyze mucus containing goblet cells, thicknesses of smooth muscle and basement membrane. All histological analyses were carried out with MS Basic Image Analyser Software (Microsystem, Computerized Microscope Systems Ltd, Beykoz, Istanbul, Turkey), which was adapted on an Olympus BH2-RFCA model microscope. The airways were classified as small $(<500 \mu \mathrm{m})$, medium $(500-1000 \mu \mathrm{m})$ and large $(>1000 \mu \mathrm{m})$ according to their circumferences. Measurements were made on distal airways cut in transverse section and free of branching. Measurement of thicknesses of epithelial, basement membrane, subepithelial smooth muscle layer, number of hyperplasic goblet cells and inflammation area on airways were recorded.

\subsection{Determination of Eosinophil Numbers in the Bone Marrow}

Cellular samples from bone marrow of mice were obtained by aspirating right femur marrow space of each animal. Cytospins were prepared, and slides were stained with $\mathrm{H} \&$ \& . Cell differentiation was determined by counting at least 300 cells under light microscopy. Eosinophils were defined as cells containing eosinophilic granules.

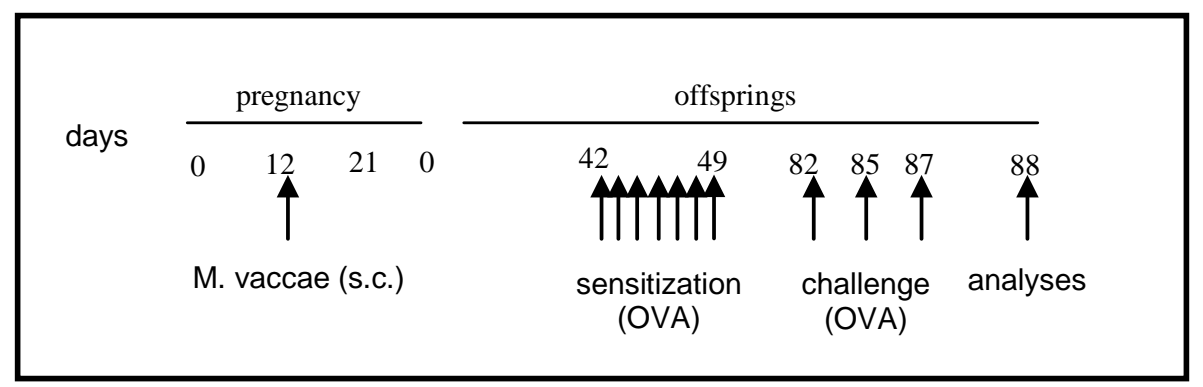

Figure 1. Study design. Pregnant BALB/c mice were divided into two groups; First group received $M$. vaccae subcutaneously on $12^{\text {th }}$ day of pregnancy while second group received only PBS. After labour newborn mice of each group were further divided into two subgroups. First subgroups named as M. vaccae/OVA and PBS/OVA. Asthma model was established by 7 i.p. OVA (sensitization) and 3 i.t. OVA (challenge) instillation. Second subgroups named as $M$. vaccae/control and PBS/control and served as negative control of asthma group. 


\subsection{Cytokine Level Determinations}

Spleens were removed from all groups, tissue was dispersed into single-cell suspension, and mononuclear cells were purified by means of Histopaque gradient centrifugation (Sigma, St. Lois MO, USA). Cells were washed, counted and suspended in RPMI 1640 (Sigma, St. Lois MO, USA) tissue culture medium containing heat-inactivated $10 \%$ FCS, $100 \mathrm{mg} / \mathrm{mL}$ penicillin, $100 \mathrm{mg} / \mathrm{mL}$ streptomycin, $5 \mathrm{mmol} / \mathrm{L} \mathrm{L}$-glutamine, and $50 \mathrm{mmol} / \mathrm{L}$ 2-mercaptoethanol (all from Sigma, St. Lois MO, USA). Then splenocytes were stimulated with OVA (40 $\mu \mathrm{g} / \mathrm{ml})$, PHA $\left(1 \mu \mathrm{g} / \mathrm{ml}\right.$, Sigma, St. Lois MO, USA) and M. vaccae $\left(2 \times 10^{7} \mathrm{CFU} / \mathrm{ml}\right)$. After 24 (for IL-10 and IFN- $\gamma$ levels detection), and 48 hours (for IL-5 level detection) supernatants were harvested. Cytokine levels of culture supernatants were determined with commercial ELISA kit (Endogen, Rockford, USA).

\subsection{Statistical Analyses}

For statistical analyses, SPSS package (release 10.1 SPSS inc., Chicago, IL, USA) program was used. Kruskal Wallis test was used for comparison of all groups. When differences were statistically significant, Mann-Whitney $U$-test was used to differentiate between the groups. A p-value less than 0.05 was considered statistically significant.

\section{Results}

\subsection{Histopathology and Bone Marrow Eosinophils}

Establishment of murine asthma model. The PBS/OVA group had statistically significantly higher numbers of hyperplasic goblet cells, increased thickness of basement membrane in all of three classified airways, also increased epithelial thickness of small and large airways, increased subepithelial smooth muscle thickness of small airways, increased density of bronchus associated lymphoid tissue (BALT) when compared to PBS/control group. The number of eosinophil progenitors in bone marrows was found to be significantly higher compared to PBS/control group (Table 1, Figures 2-5). These results indicated that the OVA asthma model was successfully established.

Effect of M. vaccae immunization to pregnants. Comparison of M. vaccae/OVA offsprings with PBS/control counterparts revealed no statistically significant difference in the number of hyperplasic goblet cells in all classified airways, epithelial thickness of large airways, basement membrane thickness of small and large airways, subepithelial smooth muscle thickness of large airways as well as BALT density and progenitors of eosinophils in the bone marrow. In addition, when the M. vaccae/OVA group was compared with PBS/OVA group, number of hyperplasic goblet cells in all airways, thickness of basement membrane of small and large airways, smooth muscle thickness of small airways, BALT density and number of eosinophil progenitors in the bone marrow were found to be significantly less in the M. vaccae/OVA group (Table 1, Figures 2-5).

\subsection{Cytokine Levels}

In the OVA asthma model, the $M$. vaccae treated animals had significantly lower IL-5 levels than the PBS/OVA treated group ( $<0.05$ ). There were no statistically significant differences in the comparison of IL-10 and IFN- $\gamma$ levels between groups. On the other hand OVA induced IL-10 levels tended to be higher in the M. vaccae/OVA group compared to other groups (Figure 6).

\section{Discussion}

In the current study we evaluated whether in utero exposure to a Th1 stimulant, could prevent against the development of murine asthma model in the offsprings. To test this hypothesis a single injection of the potent Th1 stimulant $M$. vaccae was administered to pregnant BALB/c mice at a time point which referred to the second trimester of their pregnancy.

There are significant changes that occur in the maternal immune system during pregnancy with an associated shift from a Th1 to Th2 response. This shift is required to protect the fetus from immunological rejection despite not associated with a general immunosuppression in the mother [20].

Plasma concentrations of cytokines have been shown to change with the state of pregnancy but results are conflicting [21]. Maternal plasma IL-1 $\beta$, TNF- $\alpha$, IFN- $\gamma$ [22] [23] and IL-10 [24] has been found to be absent or 
Table 1. Histopathological analyses of airways.

\begin{tabular}{|c|c|c|c|c|}
\hline Pregnancy & M. vaccae & M. vaccae & PBS & PBS \\
\hline \multirow[t]{2}{*}{ Offsprings } & OVA & control & OVA & control \\
\hline & Mean (range) & Mean (range) & Mean (range) & Mean (range) \\
\hline \multicolumn{5}{|l|}{ Goblet cell number } \\
\hline Small airways & $17.0(7-35)^{*+}$ & $0(0-0)$ & $263.3(170-330)^{Y}$ & $0(0-0)$ \\
\hline Medium airways & $49.3(10-92)^{*+}$ & $0(0-0)^{*}$ & $271.6\left(245-320^{\dagger ¥}\right.$ & $0(0-0)^{Y}$ \\
\hline Large airways & $181.3(21-263)^{* \dagger}$ & $0(0-0)^{*}$ & $378.3(317-480)^{\dagger y}$ & $0(0-0)^{¥}$ \\
\hline \multicolumn{5}{|l|}{ Epithelial thickness } \\
\hline Small airways & $23.9(20-30.9)^{* \neq}$ & $12.0(10.7-12.5)^{*}$ & $29.5(17.4-45.2)^{y}$ & $10.3(9.8-11.1)^{\ddagger ¥}$ \\
\hline Medium airways & $29.0(20-37.2)^{* \ddagger}$ & $13.8(10.7-18.9)^{*}$ & $27.5(18-40.5)$ & $17.5(17.1-22)^{\ddagger}$ \\
\hline Large airways & $31.1(15.3-39.7)$ & $14.9(10.5-20.8)$ & $33.2(21.8-41.4)^{Y}$ & $18.4(12.8-24)^{Y}$ \\
\hline \multicolumn{5}{|l|}{ Basement membrane thickness } \\
\hline Small airways & $1.3(1.2-1.6)^{\dagger}$ & $1.2(0.8-1.5)$ & $2.4(2-2.7)^{\dagger \underline{q}}$ & $1.1(0.8-1.5)^{Y}$ \\
\hline Medium airways & $1.7(1.5-2.2)^{* \ddagger}$ & $1.1(1.1-1.4)^{*}$ & $2.5(2.1-3.3)^{Y}$ & $1.3(1.2-1.4)^{\ddagger Y}$ \\
\hline Large airways & $1.8(1.6-1.9)^{\dagger}$ & $1.3(1.2-1.6)$ & $2.5(2-3)^{\dagger \Psi}$ & $1.6(1.5-1.8)^{y}$ \\
\hline \multicolumn{5}{|l|}{ Subepithelial smooth muscle thickness } \\
\hline Small airways & $5.7(5.1-6.1)^{\dagger \neq}$ & $4.2(3.4-5.3)$ & $10.9(9.8-11.9)^{\dagger \vee}$ & $3.3(3.2-3.6)^{\ddagger ¥}$ \\
\hline Medium airways & $8.0(5.9-11)^{* \ddagger}$ & $4.4(3.5-5.4)^{*}$ & $7.4(5.5-10)$ & $5.2(4.4-5.7)^{\ddagger}$ \\
\hline Large airways & $7.4(6.5-8.4)^{*}$ & $5.3(4.4-6.2)^{*}$ & $7.0(5.3-10.3)$ & $7.6(6.2-6.9)$ \\
\hline BALT density $\mu \mathrm{m}^{2}$ & $3539.6(3202-3916)^{* \dagger}$ & $598(405-734)^{*}$ & $4862.6(4604-5133)^{\dagger ¥}$ & $596.3(370-754)^{*}$ \\
\hline Eosinophil progenitors in bone marow & $25.6(18-30)^{* \dagger}$ & $5.3(4-6)^{*}$ & $40.6(35-46)^{\dagger ¥}$ & $10.3(7-16)^{y}$ \\
\hline
\end{tabular}

${ }^{*}$ Comparision of M. vaccae/OVA and M. vaccae/control groups. P $<0.05 .{ }^{\dagger}$ Comparison of $M$. vaccae/OVA and PBS/OVA groups. $\mathrm{P}<0.05$. ${ }^{\ddagger}$ Comparision of M. vaccae/OVA and PBS/control groups. $\mathrm{P}<0.05$. ${ }^{\mathrm{x}}$ Comparision of PBS/OVA and PBS/control groups. $\mathrm{P}<0.05$.

at low levels during normal pregnancy. While others report a decrease in maternal plasma IFN- $\gamma$ and IL-10 and no change in IL-6 [25] [26]. Excessive amounts of Th1 type cytokines hampers the immunologic tolerance of the female to the foreign antigens of the fetus. Increased expression of Th1 cytokines or an increased ratio of Th1/Th2 cytokines has been observed at the feto-metarnal interface in abortion-prone mice [27]. This occurs not only at the feto-maternal interface but also in human pregnancy failures [28]-[30]. In a recent study maternal transfer of protection from development of allergic airway disease to offspring in a murine model of maternal Th1 type immunity was demonstrated to be ag-specific. This study also confirmed that the transfer of maternal factors would impact on the development of immune response in offspring [11].

It has been demonstrated that healthy non-atopic subjects have detectable allergen-specific T-reg cells mediating their function through IL-10 and/or TGF- $\beta$ production, suggesting an important contribution of T-reg, Tr1-like cells to the immune regulation in allergy [31]. Also Kearly et al. clearly showed that transfer of $\mathrm{CD}^{+} \mathrm{CD}^{+} 5^{+} \mathrm{T}$ cells suppresses the Th-2 cell-driven response to allergen in vivo by an IL-10-dependent mechanism [32]. Recent data showed that cord blood mononuclear cells of atopic mothers had significantly lower expression of the Treg cells and Treg-associated markers GITR and LAG3, and trend wise lower expression for Foxp3 and CTLA4 after innate stimulation [33].

In recent studies, injection of $M$. vaccae into ovalbumin (OVA)-sensitized mice decreased Th2 type response such as eosinophilia and interleukin (IL)-4 expression [34]. It was also shown that intragastric administration of M. vaccae inhibited pulmonary allergic inflammation in murine models with increased production of IL-10 and IFN- $\gamma$ [35]. In the agreement with these findings, we showed that OVA induced IL-10 levels tended to be higher in the M. vaccae/OVA group compared to other groups. Also recently it was shown that even a single dose of injection of heat-killed $M$. vaccae was capable of treating mild to moderate atopic dermatitis in dogs [36]. Moreover Arkwright et al., reported clinical efficacy of M. vaccae (SRL172) in children with moderate to severe atopic dermatitis [37]. In a previous study of our group, we demonstrated that M. vaccae immunization to newborn mice prevented the development of histopathologic changes in a murine asthma model [16]. 


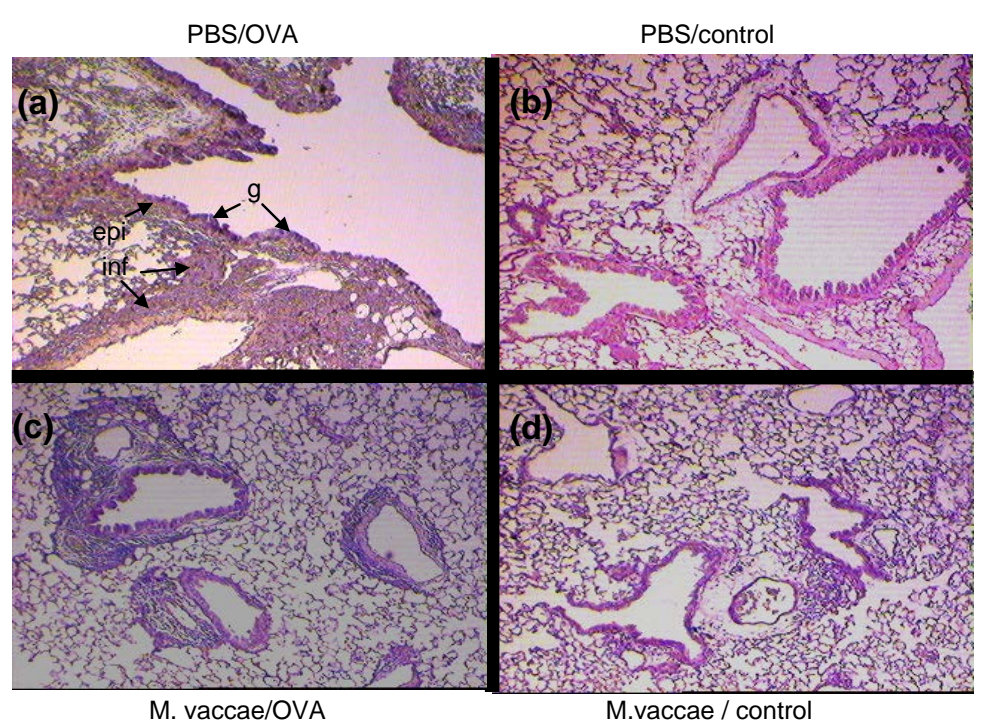

airways of all groups. PAS staining / 40x

Figure 2. Histopathologic analyses of airways. Lungs of all groups were taken 1 day after last intratracheal OVA instillation. They were fixed in formaldehyde and embedded to paraffin. Sections were stained with PAS and analysed under light microscope with 40x magnification. (a), In the PAS stain examinations of airways sections of mice in the murine model of lung sections of mice in PBS/OVA group, numerous goblet cells (g), and increased thickness of epithelial layer (epi) were seen. Also marked peribronchial and perivascular inflammations (inf) were observed. PBS/control (b), M. vaccae /OVA (c), M. vaccae/control (d).

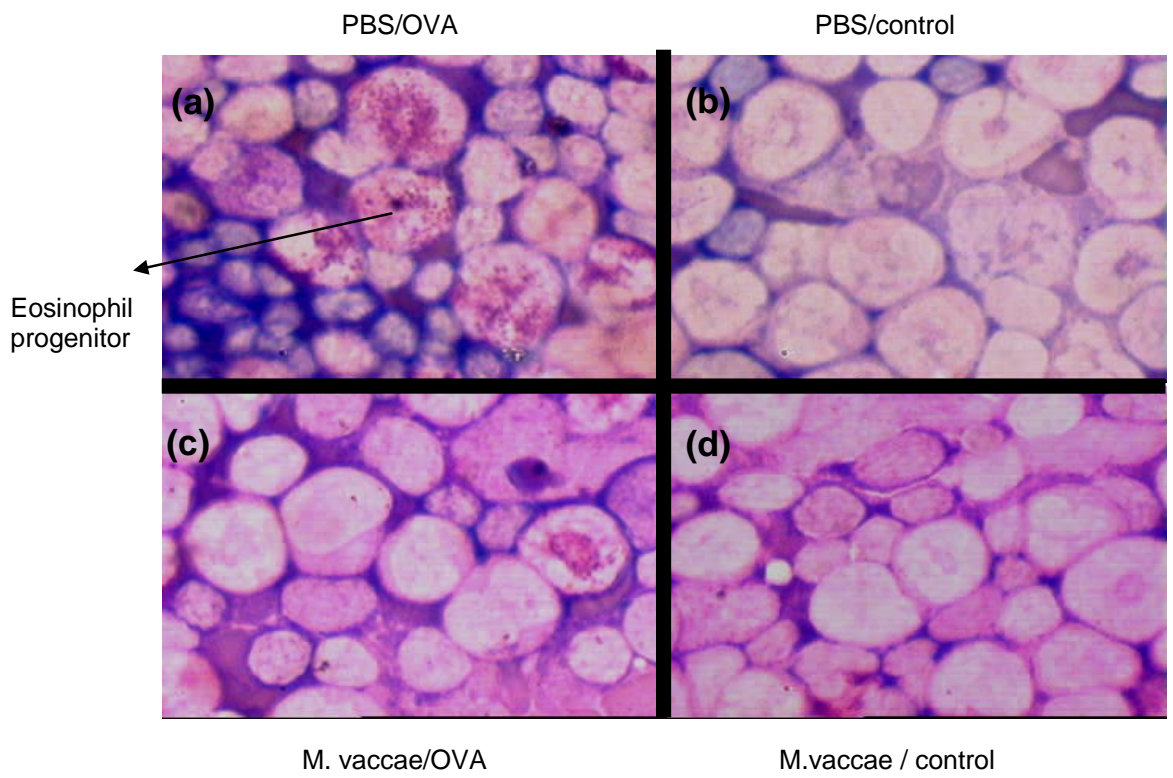

Figure 3. Bone marrow of mice with Hematoxylin \& Eosin (H \& E) staining. Eosinophilic progenitor cells were seen in PBS/OVA group (a). PBS/control (b), M. vaccae/OVA (c), $M$. vaccae/control (d). Magnification 100×.

Experimental evidence was sufficient to support the role of heat-killed $M$. vaccae in inhibiting allergen-induced airway inflammation. Short-term beneficial effects of systemic M. vaccae administration were shown to be present and use of microbial-derived materials as a potential source of new therapeutics for the treatment of 

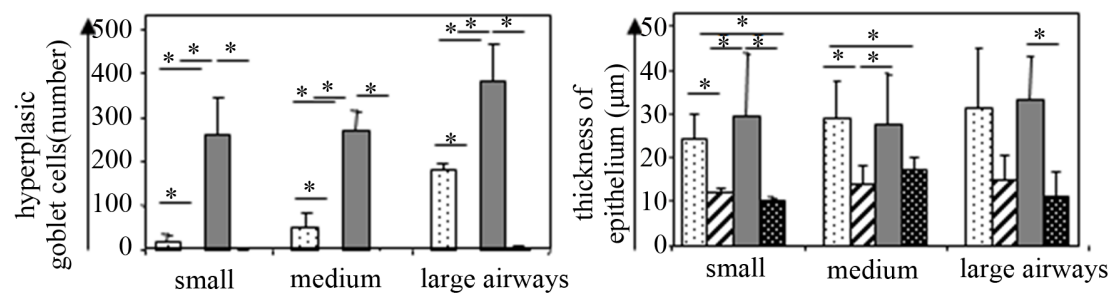

$\square$ M. vacceae/OVA

\section{$\square$ M. vacceae/control $\square \mathrm{PBS} / \mathrm{OVA}$}
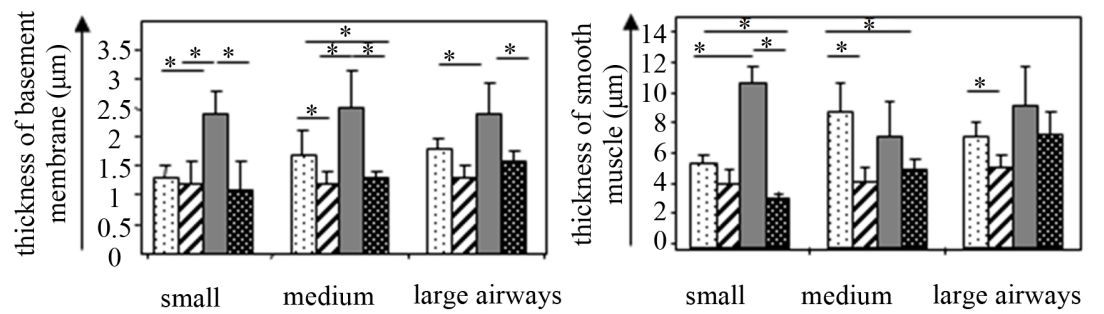

PBS/control

Figure 4. Microscopic findings of small, medium and large airways. Number of hyperplasic goblet cells and thickness of basement membrane decreased significantly in all airways, but thickness of epithelium did not significantly changed in the airways. Thickness of smooth muscle also decreased in only small airways. * $<<0.05$, statistically significant.
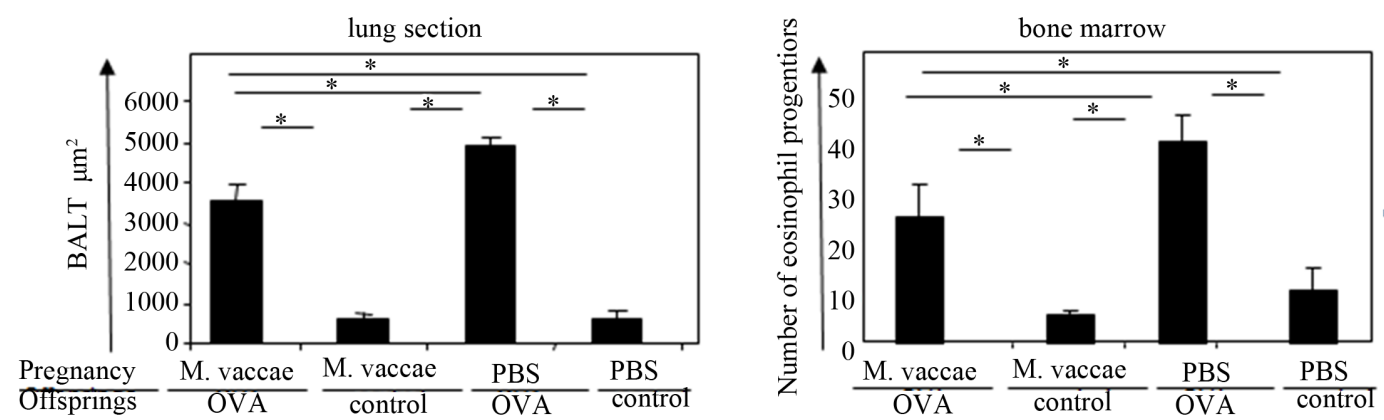

Figure 5. Effect of $M$. vaccae immunization to pregnant BALB/c mice on the formation of BALT (inflammation) in the lung and number of eosinophil progenitors in the bone marrow. ${ }^{*}$ Comparison of groups $\mathrm{p}<$ 0.05 .

asthma and allergic disorders lead to suppressed Th2 driven responses in murine asthma models [38]-[42]. Beside the short term effect of $M$. vaccae, a study from our group showed that intratracheal treatment with heatkilled $M$. vaccae administered 28 days after sensitization along with intratracheal allergen challenge was able to ameliorate histopathologic parameters of airways which persisted 24 days after the treatment [43].

Our results demonstrated that $M$. vaccae immunization to mothers during pregnancy did not result in abortion. Moreover, M. vaccae ameliorated eosinophilia in bone marrow and airway histopathologic features seen in murine asthma models such as hyperplasic goblet cells, basement membrane and smooth muscle thickening and a reduction in BALT density in OVA-sensitized and challenged offsprings. Functional measurements such as airway (lung) resistance would potentiate the strength of our experiments.

Hunt et al. showed that a single intragastric administration of $M$. vaccae in mice induced a transient increase in the production of IL-10 and IFN- $\gamma$ by mesenteric lymph nodes and splenocytes [35]. In addition Zuany-Amorim et al. demonstrated that killed $M$. vaccae gives rise to allergen-specific $\mathrm{CD} 4{ }^{+} \mathrm{CD} 45 \mathrm{RB}^{\mathrm{Lo}}$ regulatory $\mathrm{T}$ cells, which were able to protect from airway inflammation in OVA-sensitized mice [40]. In the current study, $M$. vaccae immunization to mothers revealed a down regulation of OVA-induced IL-5 secretion in two OVA-sensitized offsprings when compared to OVA-sensitized counterparts of non-immunized mothers. These results revealed that further studies are needed with more pregnant mice and their offsprings to evaluate the amount of IL-5 secretion. 

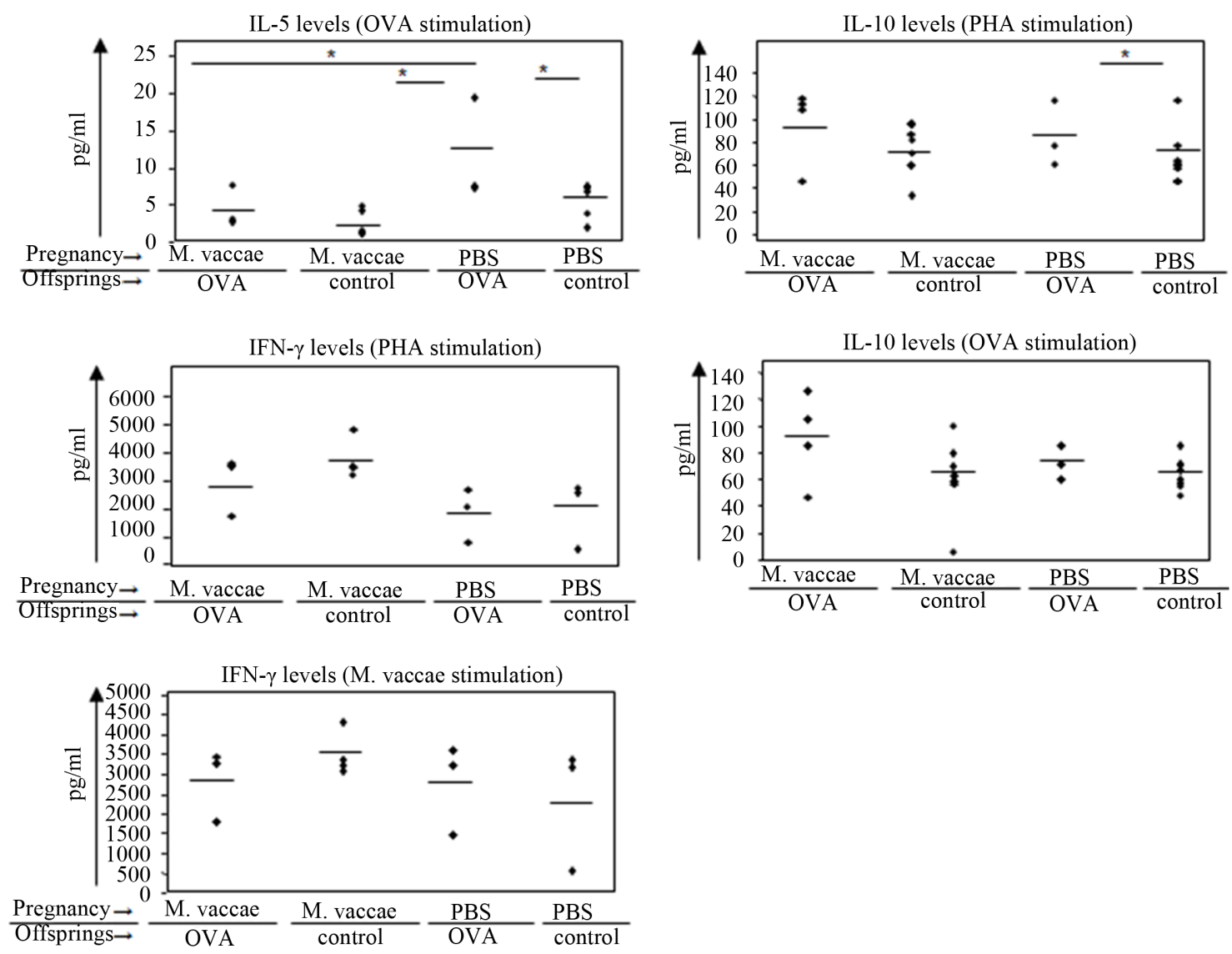

Figure 6. OVA stimulated, M. vaccae stimulated, PHA stimulated and unstimulated culture supernatants were collected and IL-10, IL-4 and IFN- $\gamma$ levels were detected by ELISA. ${ }^{*} \mathrm{p}<0.05$, statistically significant.

Recently, our group evaluated whether $M$. vaccae immunization to pregnant BALB/c mice has an effect on cytokine profile of placental and newborn mice on the $2^{\text {nd }}$ and $28^{\text {th }}$ day of life. We demonstrated that a single $M$. vaccae administration to OVA-sensitized pregnant mice down-regulated IL-5 secretion and up-regulated IFN- $\gamma$ secretion from placental lymphocytes. Moreover, this cytokine profile persisted in newborns up to the $28^{\text {th }}$ day of life [44].

It is now becoming a prerequisite to find out new therapeutic interventions before the establishment of allergic disorders. Early preventive measures which should be extremely harmless to the organism, especially to the fetus should be developed in order to gain more attraction in those strategies. M. vaccae is thought to be one of the possible promising agents among them.

\section{Conclusion}

Our results showed that $M$. vaccae immunization to pregnant BALB/c mice ameliorates lung histopathology and bone marrow eosinophilia in OVA sensitized offsprings. In addition to that, further studies which evaluate the effect of $M$. vaccae immunization to IL-5 secretion in offsprings are needed.

\section{Acknowledgements}

We thank Ismail Ogulur for critical reading of the manuscript.

\section{Declaration of Interest}

The authors report no declarations of interest. 


\section{References}

[1] Burrows, B., Martinez, F.D., Halonen, M., Barbee, R.A. and Cline, M.G. (1989) Association of Asthma with Serum IgE Levels and Skin-Test Reactivity to Allergens. The New England Journal of Medicine, 320, 271-277. http://dx.doi.org/10.1056/NEJM198902023200502

[2] Bousquet, J., Chanez, P., Lacoste, J.Y., Barneon, G., Ghavanian, N., Enander, I., Venge, P., Ahlstedt, S., Simony-Lafontaine, J., Godard, P. and Michel, F.B. (1990) Eosinophilic Inflammation in Asthma. The New England Journal of Medicine, 323, 1033-1039. http://dx.doi.org/10.1056/NEJM199010113231505

[3] Shirakawa, T., Enomoto, T., Shimazu, S. and Hopkin, J.M. (1997) The Inverse Association between Tuberculin Responses and Atopic Disorder. Science, 275, 77-79. http://dx.doi.org/10.1126/science.275.5296.77

[4] Obihara, C.C., Kimpen, J.L. and Beyers, N. (2007) The Potential of Mycobacterium to Protect against Allergy and Asthma. Current Allergy and Asthma Reports, 7, 223-230. http://dx.doi.org/10.1007/s11882-007-0076-1

[5] Cohn, L., Elias, J.A. and Chupp, G.L. (2004) Asthma: Mechanisms of Disease Persistence and Progression. Annual Review of Immunology, 22, 789-815. http://dx.doi.org/10.1146/annurev.immunol.22.012703.104716

[6] Ober, C. and Thompson, E.E. (2005) Rethinking Genetic Models of Asthma: The Role of Environmental Modifiers. Current Opinion in Immunology, 17, 670-678. http://dx.doi.org/10.1016/j.coi.2005.09.009

[7] Wills-Karp, M., Santeliz, J. and Karp, C.L. (2001) The Germless Theory of Allergic Disease: Revisiting the Hygiene Hypothesis. Nature Reviews Immunology, 1, 69-75. http://dx.doi.org/10.1038/35095579

[8] Martinez, F.D., Wright, A.L., Taussig, L.M., Holberg, C.J., Halonen, M., Morgan, W.J. (1995) Asthma and Wheezing in the First Six Years of Life. The Group Health Medical Associates. The New England Journal of Medicine, 332, 133-138. http://dx.doi.org/10.1056/NEJM199501193320301

[9] Litonjua, A.A., Carey, V.J., Burge, H.A., Weiss, S.T. and Gold, D.R. (1998) Parental History and the Risk for Childhood Asthma: Does Mother Confer More Risk Than Father? American Journal of Respiratory and Critical Care Medicine, 158, 176-181. http://dx.doi.org/10.1164/ajrccm.158.1.9710014

[10] Kurukulaaratchy, R.J., Matthews, S., Waterhouse, L. and Arshad, S.H. (2003) Factors Influencing Symptom Expression in Children with Bronchial Hyperresponsiveness at 10 Years of Age. Journal of Allergy and Clinical Immunology, 112, 311-316. http://dx.doi.org/10.1067/mai.2003.1623

[11] Matson, A.P., Zhu, L., Lingenheld, E.G., Schramm, C.M., Clark, R.B., Selander, D.M., Thrall, R.S., Breen, E. and Puddington, L. (2007) Maternal Transmission of Resistance to Development of Allergic Airway Disease. The Journal of Immunology, 179, 1282-1291. http://dx.doi.org/10.4049/jimmunol.179.2.1282

[12] Ho, Y.S., Adroub, S.A., Abadi, M., Alwan, B.A., Alkhateeb, R., Gao, G., Ragab, A., Shahjahan, A., van Soolingen, D., Bitter, W., Pain, A. and Abdallah, A.M. (2012) Complete Genome Sequence of Mycobacterium vaccae Type Strain ATCC 25954. Journal of Bacteriology, 194, 6339-6340. http://dx.doi.org/10.1128/JB.01462-12

[13] Wang, C.C. and Rook, G.A. (1998) Inhibition of an Established Allergic Response to Ovalbumin in Balb/c Mice by Killed Mycobacterium vaccae. Immunology, 93, 307-313. http://dx.doi.org/10.1046/j.1365-2567.1998.00432.x

[14] Hopfenspirger, M.T., Parr, S.K., Hopp, R.J., Townley, R.G. and Agrawal, D.K. (2001) Mycobacterial Antigens Attenuate Late Phase Response, Airway Hyperresponsiveness, and Bronchoalveolar Lavage Eosinophilia in a Mouse Model of Bronchial Asthma. International Immunopharmacology, 1, 1743-1751. http://dx.doi.org/10.1016/S1567-5769(01)00084-4

[15] Zuany-Amorim, C., Manlius, C., Trifilieff, A., Brunet, L.R., Rook, G., Bowen, G., Pay, G. and Walker, C. (2002) Long-Term Protective and Antigen Specific Effect of Heat-Killed Mycobacterium vaccae in a Murine Model of Allergic Pulmonary Inflammation. The Journal of Immunology, 169, 1492-1499. http://dx.doi.org/10.4049/jimmunol.169.3.1492

[16] Ozdemir, C., Akkoc, T., Bahceciler, N.N., Kucukercan, D., Barlan, I.B. and Basaran, M.M. (2003) Impact of Mycobacterium vaccae Immunization on Lung Histopathology in a Murine Model of Chronic Asthma. Clinical \& Experimental Allergy, 33, 266-270. http://dx.doi.org/10.1046/j.1365-2222.2003.01595.x

[17] Walker, C., Sawicka, E. and Rook, G.A. (2003) Immunotherapy with Mycobacteria. Current Opinion in Allergy \& Clinical Immunology, 3, 481-486. http://dx.doi.org/10.1097/00130832-200312000-00010

[18] Dunstan, J.A., Brothers, S., Bauer, J., Hodder, M., Jaksic, M.M., Asher, M.I. and Prescott, S.L. (2011) The Effects of Mycobacteria vaccae Derivative on Allergen-Specific Responses in Children with Atopic Dermatitis. Clinical \& Experimental Immunology, 164, 321-329. http://dx.doi.org/10.1111/j.1365-2249.2011.04371.x

[19] Akkoc, T., Tolunay, S., Barlan, I. and Basaran, M. (2001) Airway Remodeling and Serum Total Immunoglobulin E (IgE) Levels in a Murine Model of Asthma. Journal of Asthma, 38, 585-591. http://dx.doi.org/10.1081/JAS-100107123

[20] Wegmann, T.G., Lin, H., Guilbert, L. and Mosmann, T.R. (1993) Bidirectional Cytokine Interactions in the Maternal-Fetal Relationship: Is Successful Pregnancy a TH2 Phenomenon? Immunology Today, 14, 353-356. 
http://dx.doi.org/10.1016/0167-5699(93)90235-D

[21] Ostensen, M., Forger, F. and Villiger, P.M. (2006) Cytokines and Pregnancy in Rheumatic Disease. Annals of the New York Academy of Sciences, 1069, 353-363. http://dx.doi.org/10.1196/annals.1351.033

[22] Hebisch, G., Neumaier-Wagner, P.M., Huch, R. and von Mandach, U. (2004) Maternal Serum İnterleukin-1 Beta, -6 and -8 Levels and Potential Determinants in Pregnancy and Peripartum. Journal of Perinatal Medicine, 32, 475-480. http://dx.doi.org/10.1515/JPM.2004.131

[23] Opsjon, S., Austgulen, R. and Waage, A. (1995) Interleukin-1, İnterleukin-6 and Tumor Necrosis Factor at Delivery in Preeclamptic Disorders. Acta Obstetricia et Gynecologica Scandinavica, 74, $19-26$. http://dx.doi.org/10.3109/00016349509009937

[24] Makhseed, M., Raghupathy, R., Azizieh, F., Farhat, R., Hassan, N. and Bandar, A. (2000) Circulating Cytokines and CD30 in Normal Human Pregnancy and Recurrent Spontaneous Abortions. Human Reproduction, 15, 2011-2017. http://dx.doi.org/10.1093/humrep/15.9.2011

[25] Ellis, J., Wennerholm, U.B., Bengtsson, A., Lilja, H., Pettersson, A., Sultan, B., Wennergren, M. and Hagberg, H. (2001) Levels of Dimethylarginines and Cytokines in Mild and Severe Preeclampsia. Acta Obstetricia et Gynecologica Scandinavica, 80, 602-608.

[26] Russwurm, G.P., Mackler, A.M., Fagoaga, O.R., Brown, W.S., Sakala, E.P., Yellon, S.M. and Nehlsen-Cannarella, S.L. (1997) Soluble Human Leukocyte Antigens, Interleukin-6, and Interferon-Gamma during Pregnancy. American Journal of Reproductive Immunology, 38, 256-262. http://dx.doi.org/10.1111/j.1600-0897.1997.tb00512.x

[27] Tangri, S., Wegmann, T.G., Lin, H. and Raghupathy R. (1994) Maternal Anti-Placental Reactivity in Natural, Immunologically-Mediated Fetal Resorptions. The Journal of Immunology, 152, 4903-4911.

[28] Raghupathy, R. (2001) Pregnancy: Success and Failure within the TH1/TH2/Th3 Paradigm. Seminars in Immunology, 13, 219-227. http://dx.doi.org/10.1111/j.1600-0897.1997.tb00512.x

[29] Raghupathy, R., Makhseed, M., Azizieh, F., Omu, A., Gupta, M. and Farhat, R. (2000) Cytokine Production by Maternal Lymphocytes during Normal Human Pregnancy and in Unexplained Recurrent Spontaneous Abortion. Human Reproduction, 15, 713-738. http://dx.doi.org/10.1093/humrep/15.3.713

[30] Saito, S., Sakai, M., Sasaki, Y., Tanebe, K., Tsuda, H. and Michimata, T. (1999) Quantitative Analysis of Peripheral Blood Th0, TH1, TH2 and the TH1:TH2 Cell Ratio during Normal Human Pregnancy and Preeclampsia. Clinical and Experimental Immunology, 117, 550-555. http://dx.doi.org/10.1046/j.1365-2249.1999.00997.X

[31] Akdis, M., Verhagen, J., Taylor, A., Karamloo, F., Karagiannidis, C., Crameri, R., Thunberg, S., Deniz, G., Valenta, R., Fiebig, H., Kegel, C., Disch, R., Schmidt-Weber, C.B., Blaser, K. and Akdis, C.A. (2004) Immune Responses in Healthy and Allergic Individuals Are Characterized by a Fine Balance between Allergen-Specific T Regulatory 1 and T Helper 2 Cells. The Journal of Experimental Medicine, 199, 1567-1575. http://dx.doi.org/10.1084/jem.20032058

[32] Kearley, J., Barker, J.E., Robinson, D.S. and Lloyd, C.M. (2005) Resolution of Airway Inflammation and Hyperreactivity after in Vivo Transfer of $\mathrm{CD} 4^{+} \mathrm{CD} 25^{+}$Regulatory $\mathrm{T}$ Cells Is Interleukin 10 Dependent. The Journal of Experimental Medicine, 202, 1539-1547. http://dx.doi.org/10.1084/jem.20051166

[33] Schaub, B., Liu, J., Höppler, S., Haug, S., Sattler, C., Lluis, A., Illi, S. and von Mutius, E. (2008) Impairment of T-Regulatory Cells in Cord Blood of Atopic Mothers. The Journal of Allergy and Clinical Immunology, 121, 1491-1499. http://dx.doi.org/10.1016/j.jaci.2008.04.010

[34] Adams, V.C., Hunt, J.R., Martinelli, R., Palmer, R., Rook, G.A. and Brunet, L.R. (2004) Mycobacterium vaccae Induces a Population of Pulmonary CD11c ${ }^{+}$Cells with Regulatory Potential in Allergic Mice. European Journal of Immunology, 34, 631-638. http://dx.doi.org/10.1002/eji.200324659

[35] Hunt, J.R., Martinelli, R., Adams, V.C., Rook, G.A. and Brunet, L.R. (2005) Intragastric Administration of Mycobacterium vaccae Inhibits Severe Pulmonary Allergic Inflammation in a Mouse Model. Clinical \& Experimental Allergy, 35, 685-690. http://dx.doi.org/10.1111/j.1365-2222.2005.02239.x

[36] Ricklin Gutzwiller, M.E., Reist, M., Peel, J.E., Seewald, W., Brunet, L.R. and Roosje, P.J. (2007) Intradermal Injection of Heat-Killed Mycobacterium vaccae in Dogs with Atopic Dermatitis: A Multicentre Pilot Study. Veterinary Dermatology, 18, 87-93. http://dx.doi.org/10.1111/j.1365-3164.2007.00579.x

[37] Arkwright, P.D. and David, T.J. (2001) Intradermal Administration of a Killed Mycobacterium vaccae Suspension (SRL 172) Is Associated with Improvement in Atopic Dermatitis in Children with Moderate-to-Severe Disease. The Journal of Allergy and Clinical Immunology, 107, 531-534. http://Dx.doi.org/10.1067/mai.2001.113081

[38] Nahori, M.A., Lagranderie, M., Lefort, J., Thouron, F., Joseph, D., Winter, N., Gicquel, B., Silva, J.R.L.E. and Vargaftig, B.B. (2001) Effects of Mycobacterium bovis BCG on the Development of Allergic Inflammation and Bronchial Hyperresponsiveness in Hyper-IgE BP2 Mice Vaccinated as Newborns. Vaccine, 19, 1484-1495. http://dx.doi.org/10.1016/S0264-410X(00)00345-5

[39] Hopfenspirger, M.T., Parr, S.K., Hopp, J.R., Townley, R.G. and Agrawal, D.K. (2001) Mycobacterial Antigens Atte- 
nuate Late Phase Response, Airway Hyperresponsiveness, and Bronchoalveolar Lavage Eosinophilia in a Mouse Model of Bronchial Asthma. International Immunopharmacology, 1, 1743-1751.

http://dx.doi.org/10.1016/S1567-5769(01)00084-4

[40] Zuany-Amorim, C., Sawicka, E., Manlius, C., Le Moine, A., Brunet, L.R., Kemeny, D.M., Bowen, G., Rook, G. and Walker, C. (2002) Suppression of Airway Eosinophilia by Killed Mycobacterium vaccae-Induced Allergen-Specific Regulatory T-Cells. Nature Medicine, 8, 625-629. http://dx.doi.org/10.1038/nm0602-625

[41] Erb, K.J., Holloway, J.W., Sobeck, A., Moll, H. and Le Gros, G. (1998) Infection of Mice with Mycobacterium bovisBacillus Calmette-Guérin (BCG) Suppresses Allergen-Induced Airway Eosinophilia. The Journal of Experimental Medicine, 187, 561-569. http://dx.doi.org/10.1084/jem.187.4.561

[42] Ozdemir, C., Yazi, D., Aydogan, M., Akkoc, T., Bahceciler, N.N., Strong, P. and Barlan, I.B. (2006) Treatment with Chitin Microparticles Is Protective against Lung Histopathology in a Murine Asthma Model. Clinical \& Experimental Allergy, 36, 960-968. http://dx.doi.org/10.1111/j.1365-2222.2006.02515.X

[43] Yazi, D., Akkoc, T., Ozdemir, C., Yesil, O., Aydogan, M., Sancak, R., Bahceciler, N.N. and Barlan, I.B. (2007) LongTerm Modulatory Effect of Mycobacterium vaccae Treatment on Histopathologic Changes in a Murine Model of Asthma. Annals of Allergy, Asthma \& Immunology, 98, 573-579. http://dx.doi.org/10.1016/S1081-1206(10)60738-7

[44] Akkoc, T., Eifan, A., Ozdemir, C., Yazi, D., Yesil, Ö., Bahçeciler, N.N. and Barlan, I.B. (2008) Mycobacterium vaccae Immunization to OVA Sensitized Pregnant BALB/c Mice Suppresses Placental and Postnatal IL-5 and Inducing IFNGamma Secretion Immunopharmacol. Immunopharmacology and Immunotoxicology, 30, 1-11. http://dx.doi.org/10.1080/08923970701812159 